Formatif: Jurnal Ilmiah Pendidikan MIPA

Vol. 9, No. 4, December 2019, pp. 281-290

p-ISSN: 2088-351X

e-ISSN: 2502-5457

DOI: http://dx.doi.org/10.30998/formatif.v9i4.3489

\title{
Development of JINEMAM Learning Model
}

\author{
Pengembangan Model Pembelajaran JINEMAM
}

Dwi Candra Setiawan (*)

IKIP Budi Utomo Malang

Deny Setiawan

Universitas Negeri Malang

Received: March 15, 2019

Revised: August 09, 2019

Accepted: October 30, 2019

\begin{abstract}
The research aims to produce a learning model that is expected to be easy, effective and practically applied in the learning process. The model developed is the JINEMAM model which is a combination of the Jigsaw, Example Non Example and Make a Match model. This research in its development process uses the $4 \mathrm{D}$ development model from thiagarajan namely Define, Design, Develop and Disseminate. The instruments used were validation sheets, legibility questionnaires and pretest-posttest questions. For product trials and legibility using 32 students of the 2014 Biology study program. The results of the data analysis showed that the learning model was very valid. Based on the results of the analysis it can be concluded that the learning model is feasible to be used in the learning process.
\end{abstract}

Keywords: JINEMAM, Development, 4D

(*) Corresponding Author: $\quad$ dwicandra14@gmail.com.- 085649549114

How to Cite: Setiawan, D. C. \& Setiawan, D. (2019). Development of JINEMAM learning model. Formatif: Jurnal Ilmiah Pendidikan MIPA, 9 (2): 281-290. http://dx.doi.org/10.30998/formatif.v9i4.3489

\section{PENDAHULUAN}

Proses pembelajaran tidak bisa lepas dari penerapan suatu model pembelajaran. Penerapan suatu model pembelajaran bertujuan untuk membantu pendidik mencapai tujuan pembelajaran. Model pembelajaran juga merupakan komponen yang membantu pendidik dalam kelancaran proses mengajar (Eka, Ramli, \& Suciati, 2017). Oleh karena itu sangatlah penting seorang pendidik menguasai serta mampu mengaplikasikan berbagai macam model pembelajaran dalam KBM. Jika seorang pendidik kurang tepat atau tidak menguasai model yang ingin diterapkan, proses pembelajaran menjadi jenuh atau membosankan bagi peserta didik (Pratiwi, 2009). Pendidik juga harus kreatif dan inovatif dalam menerapkan suatu model pembelajaran dalam KBM. Kreativitas dan inovasi pendidik inilah yang pada saat ini masih minim, terutama kemampuan pendidik dalam menerapkan model pembelajaran.

Pendidik haruslah mampu secara kreatif mengembangkan model pembelajaran yang menarik dan memudahkan pendidik maupun peserta didik mencapai tujuan pembelajaran yang diinginkan. Sayangnya, pengembangan model pembelajaran baru yang dihasilkan oleh pendidik sangatlah minim. Hal ini dapat dilihat dan dibuktikan dari penggunaan model-model pembelajaran yang dimanfaatkan oleh pendidik dan juga oleh mahasiswa yang melakukan penelitian masih terpaku pada model pembelajaran yang 
Formatif: Jurnal Ilmiah Pendidikan MIPA

Vol. 9, No. 4, December 2019, pp. 281-290

p-ISSN: 2088-351X

e-ISSN: $2502-5457$

DOI: http://dx.doi.org/10.30998/formatif.v9i4.3489

sudah ada dan telah banyak digunakan, maka perlu dilakukan suatu usaha untuk melakukan pengembangan model pembelajaran. Salah satu cara mengembangkan model pembelajaran yaitu dengan memadupadankan beberapa model pembelajaran menjadi satu kesatuan dalam sintaks/tahapan pembelajaran. Selain itu tujuan dari pengembangan model pembelajaran juga diharapkan mampu memberdayakan kemampuan peserta didik, salah satunya kemampuan berpikir kritis dan metakognitif. Kemampuan tersebut merupakan kemampuan yang dibutuhkan untuk dibekalkan kepada peserta didik di era abad 21 ini. Hal ini sejalan dengan Zubaidah (2016) yang menyatakan bahwa berpikir kritis, pemecahan masalah, metakognisi, keterampilan berkomunikasi, berkolaborasi, inovasi, dan kreasi adalah keterampilan yang harus dibekali kepada peserta didik untuk menghadapi abad 21.

Model pembelajaran yang ada pada saat ini sudah banyak jumlahnya, tetapi di sinilah tantangan kreativitas dan inovasi pendidik untuk dapat menemukan model pembelajaran yang baru atau mengembangkan model pembelajaran yang sudah ada dengan cara dipadupadankan model satu dengan model yang lain, sehingga dapat membuat proses KBM lebih menarik. Berdasarkan beberapa model pembelajaran yang ada dan dirasa dapat dipadupadankan untuk dikembangkan suatu model pembelajaran adalah model Jigsaw, Make a Match, dan Example non Example. Ketiga model ini dapat dipadupadankan karena ketiganya merupakan model pembelajaran kooperatif. Selain itu ketiga model ini dalam salah satu langkah pembelajarannya terdapat proses diskusi dan presentasi. Perpaduan ketiga model pembelajaran kooperatif ini juga didasarkan karena ketiga model ini menekankan peserta didik untuk mampu berkolaborasi dan berkomunikasi dengan temannya dalam proses pembelajaran. Dengan adanya kolaborasi dan komunikasi ini, diharapkan pemahaman peserta didik akan lebih mendalam dan lebih baik. Hal ini sejalan dengan Musyahidin (2015) yang menyatakan bahwa pembelajaran kooperatif dalam prosesnya menekankan interaksi antarpeserta didik, sehingga peserta didik tidak hanya memperoleh pemahaman dari pendidik tetapi juga dari temannya.

Selain faktor yang telah disebutkan, alasan lain mengapa dikembangkan model JINEMAM dari ketiga model tersebut, karena dari masing-masing model tersebut mempunyai keunggulan tersendiri. Dari keunggulan inilah diharapkan dengan dipadupadankan akan lebih memberikan dampak yang positif dalam proses pembelajaran. Pertama model Jigsaw menurut Trisianawati, Djudin, \& Setiawan, (2016) merupakan suatu pembelajaran kooperatif dengan pengelompokan siswa yang heterogen, di mana peserta didik mampu dilibatkan secara aktif dalam pembelajaran dengan menjadi tim ahli untuk mengerjakan lembar diskusi ahli di masing-masing kelompok. Melalui pembelajaran ini maka peserta didik dapat mempunyai kesempatan mengemukakan pendapat, meningkatkan kemampuan berkomunikasi serta secara tidak langsung akan memberikan pemahaman yang lebih terhadap materi.

Example non Example juga merupakan bentuk pembelajaran kooperatif. Hal ini sesuai dengan pendapat Dewi, dkk (2014) yang menyatakan bahwa model Example non Example merupakan pembelajaran kooperatif yang melibatkan peran peserta didik dalam pembelajaran melalui gambar-gambar yang dapat melibatkan keaktifan peserta didik dari aspek intelektual, sosial, mental, dan emosional. Dengan demikian model ini akan mampu memberikan kesempatan yang baik bagi peserta didik untuk menemukan serta mengemukakan idenya (Suciati, 2013).

Terakhir adalah model pembelajaran Make a Match. Make a Mach adalah suatu model pembelajaran dengan teknik kerja sama, di mana masing-masing individu dalam tiap kelompok harus berusaha mencari pasangan kartu yang tepat dan cepat sesuai waktu yang telah ditentukan oleh pendidik (Zahroul \& Windy, 2014). Berdasarkan penjelasan tersebut maka peneliti tertarik menggabungkan ketiga model pembelajaran tersebut 
Formatif: Jurnal Ilmiah Pendidikan MIPA

Vol. 9, No. 4, December 2019, pp. 281-290

p-ISSN: 2088-351X

e-ISSN: $2502-5457$

DOI: http://dx.doi.org/10.30998/formatif.v9i4.3489

menjadi satu model pembelajaran yang disebut JINEMAM (Jigsaw, Example non Example, Make a Match). Dengan demikian peneliti tertarik melakukan penelitian dengan judul Pengembangan Model Pembelajaran JINEMAM. Kepentingan utama dalam penelitian ini adalah melatih dan memotivasi peneliti untuk kreatif dan inovatif dalam melaksanakan proses pembelajaran dengan memanfaatkan baik sumber, model maupun media pembelajaran yang sudah ada. Sehingga harapannya dari penelitian ini dapat ditemukan suatu model pembelajaran baru yang layak dan mudah diaplikasikan dalam proses pembelajaran di kelas serta membantu dalam memberdayakan kemampuan berpikir kritis dan metakognitif peserta didik.

\section{METODE}

Penelitian ini merupakan penelitian Research and Development (R\&D) yang diadaptasi dari Thiagarajan (1974) dengan model pengembangan 4D yaitu define, design, develop, and disseminate. Penelitian ini dilakukan sampai tahap develop saja, untuk tahap disseminate akan dilanjutkan pada periode selanjutnya. Pada tahapan define dilakukan beberapa analisis yaitu analisis ujung depan, analisis mahasiswa, analisis tugas, analisis konsep, dan analisis tujuan. Tahap design dilakukan dengan menyusun draf awal langkah pembelajaran JINEMAM dan terakhir tahap develop dilakukan uji validasi ahli model pembelajaran dan ahli bahasa serta dilakukan uji coba keterbacaan. Penelitian Ini dilaksanakan pada Maret hingga Juni 2018. Populasi pada penelitian ini adalah seluruh mahasiswa pendidikan Biologi sedangkan sampel penelitian uji coba keterbacaan adalah angkatan 2014 Kelas A sejumlah 32 orang yang diambil secara acak. Dasar pemilihan sampel ini adalah mahasiswa yang telah menempuh mata kuliah desain dan strategi pembelajaran, sehingga diharapkan mampu memberikan saran serta masukkan yang dapat membantu peneliti dalam mengembangkan model pembelajaran JINEMAM.

Data yang diperoleh berupa data kualitatif dan kuantitatif. Data kualitatif diperoleh dari hasil pengamatan dan wawancara, sedangkan data kuantitatif diperoleh dari penyebaran angket validasi dan keterbacaan produk model pembelajaran. Untuk data yang diperoleh dianalisis dengan bantuan konversi skor. Analisis data yang diperoleh melalui lembar pengisian uraian saran, kritik, dan pendapat validator terhadap petunjuk praktikum yang terdapat pada akhir masing-masing instrumen validasi model pembelajaran yang terdapat pada bagian akhir masing-masing instrumen validasi dilakukan secara deskriptif kualitatif dan hasilnya digunakan sebagai dasar perbaikan pengembangan model pembelajaran JINEMAM yang nanti akan diaplikasikan pada mata kuliah perkembangan hewan.

Teknik analisis data yang digunakan untuk menganalisis data kuantitatif berupa skor validasi kelayakan materi dan media adalah mengonversi menjadi data skala. Setelah diperoleh nilai konversi skor yang didapatkan dilanjutkan dengan menghitung persentase jawaban. Rumus yang digunakan teknik adalah analisis persentase, $\mathrm{P}=\frac{\sum X}{\sum X i} \mathrm{X} 100 \%$ Keterangan:

$\mathrm{P} \quad$ : Persentase kevalidan

$\sum X \quad$ : Jumlah jawaban validator dalam 1 item

$\sum \mathrm{Xi}:$ Jumlah jawaban ideal dalam 1 item

$100 \%$ : Konstanta (Arikunto, 2008)

Analisis data yang berupa persentase tersebut kemudian ditafsirkan dengan kalimat yang bersifat kualitatif sesuai dengan kriteria pada Tabel 1. 
Formatif: Jurnal Ilmiah Pendidikan MIPA

Vol. 9, No. 4, December 2019, pp. 281-290

p-ISSN: 2088-351X

e-ISSN: 2502-5457

DOI: http://dx.doi.org/10.30998/formatif.v9i4.3489

Tabel 1. Kriteria Validasi Model Pembelajaran

\begin{tabular}{cc}
\hline Skala nilai $(100 \%)$ & Keterangan \\
\hline $76-100$ & Valid \\
$56-75$ & Cukup valid \\
$40-55$ & Kurang valid \\
$<40$ & Tidak valid \\
\hline
\end{tabular}

Sumber: Arikunto, 1993

\section{HASIL DAN PEMBAHASAN}

\section{Hasil}

Hasil dari penelitian pengembangan model pembelajaran JINEMAM diperoleh dari pelaksanaan setiap tahapan yang dicanangkan sebelumnya. Berikut secara rinci hasil penelitian dari masing-masing tahapan penelitian:

\section{Tahap Define}

Hasil penelitian awal tahapan define yang diperoleh dalam pengembangan model pembelajaran JINEMAM dapat dijabarkan secara singkat dari tiap tahapan yang diperoleh sebagai berikut:

a. Analisis front-end (ujung depan)

Data yang diperoleh pada tahapan awal ini adalah masih terdapatnya proses pembelajaran yang sangat monoton dan bahkan diketahui dari hasil wawancara dengan beberapa mahasiswa terdapat beberapa dosen yang cara mengajarnya hanya ceramah saja tanpa menggunakan model dan media pembelajaran. Hal ini menurut mahasiswa membuat proses pembelajaran sangat membosankan dan kurang menarik minat belajar mahasiswa. Berdasarkan hasil pengamatan dan wawancara tersebut, dengan adanya upaya mengembangkan suatu model pembelajaran yang menarik serta mudah diaplikasikan dalam pembelajaran dapat mengatasi permasalahan tersebut

b. Analisis mahasiswa

Mahasiswa IKIP Budi Utomo termasuk mahasiswa Pendidikan Biologi, pada umumnya adalah mahasiswa dengan latar belakang perekonomian menengah ke bawah. Selain itu berdasarkan hasil pengamatan selama mengajar di IKIP Budi Utomo menunjukkan bahwa kemampuan kognitif mahasiswa masih rendah. Hal ini ditinjau dari rekam nilai mahasiswa selama menempuh proses perkuliahan. Berdasarkan hal tersebut, peneliti tertarik melakukan pengembangan model pembelajaran guna memberdayakan kemampuan mahasiswa tersebut, sehingga hasilnya adalah menghasilkan output mahasiswa yang setara dengan perguruan tinggi negeri.

c. Analisis tugas

Pada tahap ini peneliti mengetahui tugas atau tagihan apa yang cocok serta tepat bagi mahasiswa untuk dilakukan dalam proses pembelajaran. Melihat karakteristik mahasiswa berdasarkan hasil analisis mahasiswa sebelumnya, maka dalam proses pembelajaran dengan mengaplikasikan model JINEMAM peneliti memberikan tugas berupa permasalahan studi kasus dan gambar-gambar yang mampu merangsang kemampuan berpikir kritis dan metakognitif mahasiswa. Bentuk tugas ini sesuai dan cocok dengan model JINEMAM yang dikembangkan peneliti.

d. Analisis konsep

Hasil yang diperoleh selanjutnya adalah hasil dari tahap analisis konsep. Hasil tahap ini berkaitan dengan hasil analisis capaian pembelajaran $(\mathrm{CP})$, capaian pembelajaran mata kuliah (CPMK) dan sub-CPMK. Analisis konsep juga perlu 
Formatif: Jurnal Ilmiah Pendidikan MIPA

Vol. 9, No. 4, December 2019, pp. 281-290

p-ISSN: 2088-351X

e-ISSN: $2502-5457$

DOI: http://dx.doi.org/10.30998/formatif.v9i4.3489

mempertimbangkan kesesuaian materi sebelumnya, karakter dan kebutuhan mahasiswa, serta analisis tugas. Materi pembelajaran yang dikembangkan juga disesuaikan dengan konsep-konsep yang telah dirumuskan dari topik utama dan berdasarkan hasil dari analisis komponen RPS. Sehingga dengan demikian, pada tahap ini telah diperoleh komponen perangkat pembelajaran yang pas untuk mengaplikasikan model JINEMAM dalam proses KBM.

e. Analisis tujuan

Hasil data penelitian terakhir yang diperoleh di tahapan define adalah analisis tujuan. Dari proses analisis tujuan diperoleh tujuan pembelajaran yang akan dicapai dalam pengembangan model pembelajaran JINEMAM. Tujuan utama dari pembelajaran dengan model JINEMAM adalah mahasiswa mampu memberdayakan kemampuan berpikir kritis dan metakognitifnya.

\section{Tahap Design}

Pada tahap ini dilakukan perancangan dan penyusunan draft langkah-langkah model pembelajaran JINEMAM yang akan dikembangkan. Draft draft langkah-langkah model pembelajaran JINEMAM yang dikembangkan ini juga diharapkan sesuai dengan materi dan RPS mata kuliah struktur perkembangan hewan. Model pembelajaran JINEMAM menggunakan bahasa dan kalimat yang jelas sehingga memudahkan mahasiswa untuk memahami. Langkah dari model pembelajaran JINEMAM diperoleh dari perpaduan langkah-langkah dari model Jigsaw, Example non Example dan Make a Match.

Hasil dari tahap ini diperoleh 18 langkah model pembelajaran JINEMAM. Draf langkah awal model ini akan diuji validasi kepada para ahli dan dilakukan uji coba keterbacaan mahasiswa pada tahap develop. Berikut draf awal hasil tahapan desain langkah model JINEMAM dengan memperhatikan setiap langkah-langkah dari ketiga model yang dipadukan, yaitu: a) Pendidik mempersiapkan gambar-gambar sesuai dengan tujuan pembelajaran. Gambar-gambar yang digunakan tentunya merupakan gambar yang relevan dengan materi yang dibahas sesuai dengan Kompetensi Dasar. b) Pendidik menempelkan gambar di papan atau ditayangkan melalui LCD/OHP/In Focus. Pada tahap ini Pendidik dapat meminta bantuan peserta didik untuk memperhatikan gambar yang diberikan. c) Pendidik melakukan tanya jawab terkait gambar yang disajikan sebagi apersepsi kepada peserta didik. d) Pendidik menyampaikan materi pembelajaran dan memberikan bahan diskusi. e) Membagi 5 atau 6 peserta didik menjadi satu kelompok jigsaw. f) Masing-masing kelompok disebut Kelompok Asal dan di setiap kelompok akan terdiri tim-tim ahli satu, dua, dan seterusnya (jumlah tim ahli sesuai dengan jumlah orang di setiap Kelompok Asal). g) Memberikan permasalahan/bahan diskusi berupa gambar maupun studi kasus kepada masing-masing tim asal. h) Setiap peserta didik yang menjadi ahli dalam kelompok asal akan mempelajari dan menyelesaikan permasalahan yang menjadi tugasnya. i) Memberi waktu pada peserta didik (masing-masing tim ahli) untuk menyelesaikannya. j) Tim ahli dari masing-masing kelompok asal diminta untuk bergabung dengan tim ahli yang sama dari kelompok asal yang berbeda, kemudian mereka diminta untuk sharing dan berdiskusi dari permasalahan yang sudah dikerjakan sebelumnya. k) Tim ahli diminta kembali menuju tim asal sebelumnya untuk mempresentasikan hasil diskusi pada tim asalnya secara bergantian dari masing-masing tim ahli. 1) Kelompok Asal akan mempresentasikan hasil diskusi kelompok di depan kelas dengan bimbingan dan arahan pendidik. m) Di akhir kegiatan peserta didik diberikan evaluasi melalui game Make a Match yaitu dengan cara mencocokkan jawaban dan pertanyaan yang telah disediakan oleh pendidik. n) Setiap peserta didik mendapatkan sebuah kartu (soal atau jawaban). o) Peserta didik yang sudah mendapatkan kartu 
Formatif: Jurnal Ilmiah Pendidikan MIPA

Vol. 9, No. 4, December 2019, pp. 281-290

p-ISSN: 2088-351X

e-ISSN: 2502-5457

DOI: http://dx.doi.org/10.30998/formatif.v9i4.3489

memikirkan jawaban/soal dari kartu yang didapatkannya. p) Setiap peserta didik mencari pasangan kartu yang sekiranya cocok dengan kartu yang dimilikinya. q) Jika peserta didik tidak bisa mencocokkan kartu yang tepat atau tidak menemukan kartu yang cocok sebelum batas waktu yang ditetapkan, maka peserta didik bersangkutan tidak akan mendapatkan nilai tambah. r) Pendidik bersama peserta didik menyimpulkan hasil pembelajaran hari ini.

3. Tahap Develop

a. Validasi ahli model pembelajaran

Tahap ini dilakukan pelaksanaan validasi kepada para ahli dan uji keterbacaan produk kepada mahasiswa, yang dilakukan pada dua ahli, yaitu ahli model pembelajaran dan ahli bahasa. Hasil uji validasi ahli model pembelajaran dapat dilihat pada tabel 2 .

Tabel 2. Ringkasan Hasil Validasi Ahli Model Pembelajaran

\begin{tabular}{|c|c|c|c|c|c|}
\hline \multirow[b]{2}{*}{ Bidang Keahlian } & \multirow[b]{2}{*}{ Validator } & \multicolumn{4}{|c|}{ Validasi } \\
\hline & & $\begin{array}{c}\text { Penggunaan } \\
\text { Bahasa }\end{array}$ & $\begin{array}{c}\text { Tujuan } \\
\text { Pembel } \\
\text { ajaran }\end{array}$ & $\begin{array}{c}\text { Kelebihan } \\
\text { Model }\end{array}$ & Rerata \\
\hline $\begin{array}{l}\text { Desain dan Strategi } \\
\text { Pembelajaran } \\
\text { Desain dan Strategi }\end{array}$ & I & $95 \%$ & $100 \%$ & $100 \%$ & $98,33 \%$ \\
\hline Pembelajaran & II & $\begin{array}{l}95 \% \\
95 \%\end{array}$ & $\begin{array}{l}100 \% \\
100 \%\end{array}$ & $\begin{array}{l}100 \% \\
100 \%\end{array}$ & $\begin{array}{l}98,33 \% \\
98,33 \%\end{array}$ \\
\hline
\end{tabular}

Berdasarkan tabel 2, diperoleh hasil uji validasi ahli model pembelajaran yaitu dari validator I diperoleh penilaian tertinggi pada komponen tujuan pembelajaran sebesar $100 \%$, sedangkan nilai terendah pada komponen dan diskusi materi dengan tingkat pencapaian $95 \%$. Rerata tingkat pencapaian penilaian yang diberikan oleh validator I ialah sebesar 98,33\%. Saran yang diberikan oleh validator I antara lain 1) Sebaiknya langkah Pembelajaran perlu dipersingkat supaya tidak terlalu panjang dan lebih mudah untuk diaplikasikan, dan 2) bahasa dari setiap langkah pembelajaran lebih sederhana untuk mudah dipahami. Hasil validasi dari validator II diperoleh hasil penilaian tertinggi pada komponen tujuan pembelajaran dengan tingkat pencapaian $100 \%$, sedangkan penilaian terendah pada komponen materi pokok dengan tingkat pencapaian 95\%. Rerata tingkat pencapaian nilai yang diberikan oleh validator II ialah sebesar 98,33\%. Sarandari validator II ialah sebagai berikut: 1) Langkah Pembelajaran perlu diringkas sehingga kalimat/bahasa lebih mudah dipahami, dan 2) perbaikan beberapa tahapan. Berdasarkan hasil dari kedua validator tersebut maka kelayakan langkah-langkah model pembelajaran JINEMAM dikatakan valid dan layak untuk digunakan

b. Validator ahli bahasa

Selain divalidasi ahli oleh model pembelajaran, model pembelajaran JINEMAM juga divalidasi oleh ahli bahasa, yang bertujuan untuk menilai kelayakan bahasa dan tata cara penulisan. Hasil validasi bahasa dapat dilihat dari tabel 3

Tabel 3. Ringkasan Hasil Validasi Ahli Bahasa

\begin{tabular}{lcccc}
\hline \multirow{2}{*}{$\begin{array}{c}\text { Bidang } \\
\text { Keahlian }\end{array}$} & Validator & & \multicolumn{4}{c}{ Validasi } \\
\cline { 3 - 5 } Bahasa & Struktur Kalimat & Kejelasan & Komunikatif dan kreatif & Rerata \\
\cline { 2 - 5 } & & & & \\
\hline
\end{tabular}


Formatif: Jurnal Ilmiah Pendidikan MIPA

Vol. 9, No. 4, December 2019, pp. 281-290

p-ISSN: 2088-351X

e-ISSN: 2502-5457

DOI: http://dx.doi.org/10.30998/formatif.v9i4.3489

Berdasarkan tabel 4, hasil validasi diperoleh penggunaan bahasa pada model adalah 91,66\%, maka dapat dikatakan dari sisi bahasa langkah model JINEMAM dikatakan valid dan layak untuk digunakan. Beberapa saran yang diberikan oleh validator adalah: 1) perlu penyesuaian ejaan dan tanda baca yang sesuai dengan EYD, dan 2) langkah-langkah pembelajaran lebih disederhanakan

Berdasarkan hasil uji validasi baik dari ahli model pembelajaran dan ahli bahasa, didapatkan revisi langkah pembelajaran Model JINEMAM yaitu sebagai berikut: 1) Pendidik menyiapkan gambar, 2) melakukan tanya jawab terkait gambar yang disajikan, 3) peserta didik dibagi dalam kelompok yang terdiri 4-5 orang, 4) tiap peserta didik menjadi tim ahli untuk setiap permasalahan dalam kelompok asal, 5) tiap tim ahli dari kelompok asal bergabung dengan tim ahli yang sama dari kelompok asal lainnya, berdiskusi dan menyelesaikan masalah, 6) tim ahli kembali ke kelompok asalnya masingmasing, kemudian sharing hasil diskusi sebelumnya kepada anggota kelompok asalnya, 7) presentasi kelas hasil diskusi dipandu oleh pendidik, 8) melakukan evaluasi dengan cara peserta didik diberi kartu soal dan kartu jawaban, 9) peserta didik mencari pasangan kartu yang cocok dengan yang dimiliki, 10) peserta didik memperoleh point/nilai jika tepat mencocokkan kartu sesuai batas waktu yang ditentukan, dan 11) peserta didik dipandu pendidik menyimpulkan hasil pembelajaran

c. Uji coba keterbacaan model pembelajaran JINEMAM

Tahapan selanjutnya setelah dilakukan revisi dari hasil validasi ahli adalah melakukan uji coba produk. Uji coba ini dilakukan mulai tanggal 20 Mei 2017. Uji coba diberikan kepada mahasiswa Pendidikan Biologi Kelas A angkatan 2014 sejumlah 32 orang. Data awal yang diperoleh untuk uji coba model ini dengan melakukan uji keterbacaan langkah-langkah model JINEMAM. Uji keterbacaan ini dilakukan dengan menggunakan angket keterbacaan langkah-langkah model JINEMAM. Ringkasan hasil uji keterbacaan model JINEMAM oleh mahasiswa dapat dilihat pada tabel 4.

Tabel 4. Ringkasan Uji Keterbacaan Model

\begin{tabular}{lll}
\hline No & Aspek yang dinilai & Kriteria \\
\hline 1. & $\begin{array}{l}\text { Bahasa dan Penulisan langkah model pembelajaran (terdiri dari } \\
5 \text { butir pertanyaan) }\end{array}$ & Valid \\
2 & $\begin{array}{l}\text { Kelebihan model pembelajaran } \\
\text { (terdiri dari 6 butir pertanyaan) }\end{array}$ & Valid \\
\hline
\end{tabular}

Hasil analisis uji keterbacaan diketahui bahwa langkah dalam model JINEMAM valid. Hal ini menunjukkan bahwa langkah dalam model JINEMAM layak untuk digunakan dan dilakukan uji coba kepada mahasiswa. Berdasarkan hasil analisis data yang diperoleh dari tahap define, desing, dan develop maka dapat disimpulkan bahwa penyusunan langkah-langkah model pembelajaran JINEMAM layak untuk digunakan dalam proses pembelajaran, baik di lingkungan sekolah maupun perguruan tinggi.

\section{Pembahasan}

Kelayakan model pembelajaran model pembelajaran JINEMAM berdasarkan hasil analisis data dikarenakan langkah-langkah model pembelajaran JINEMAM telah melewati serangkaian tahapan dari setiap model pengembangan 4D. Kelayakan tersebut diperoleh setelah melalui rangkaian tahapan dari tahapan define yang terdiri atas proses analisis front end, analisis mahasiswa, analisis tugas, analisis konsep dan analisis tujuan. Kemudian dilanjutkan tahapan design untuk memperoleh draf awal langkah model 
Formatif: Jurnal Ilmiah Pendidikan MIPA

Vol. 9, No. 4, December 2019, pp. 281-290

p-ISSN: 2088-351X

e-ISSN: 2502-5457

DOI: http://dx.doi.org/10.30998/formatif.v9i4.3489

JINEMAM dan terakhir tahap develop yang melalui proses validasi dari ahli model pembelajaran, ahli bahasa dan juga melalui proses uji coba keterbacaan oleh mahasiswa. Tahapan pertama yaitu define, merupakan tahapan analisis kebutuhan yang menentukan kelayakan suatu model yang dikembangkan, karena dalam tahapan ini terdapat proses analisis front end, analisis mahasiswa, analisis tugas, analisis konsep dan analisis tujuan yang bertujuan sebagai pedoman untuk merancang suatu model pembelajaran yang cocok dan tepat untuk digunakan dan terutama untuk membantu mencapai tujuan pembelajaran yang dicanangkan. Analisis kebutuhan merupakan salah satu tahapan yang diperlukan dalam pengembangan model pembelajaran untuk mengetahui permasalahan yang dihadapi sehingga dapat diketahui langkah apa yang dibutuhkan untuk mengatasi permasalahan tersebut dan akhirnya dapat mencapai tujuan pembelajaran yang diharapkan (Dewy, 2016).

Selanjutnya penentuan kelayakan model JINEMAM diperoleh melalui tahap design dengan melewati serangkaian proses validasi terhadap beberapa ahli, dalam penelitian ini menggunakan ahli model pembelajaran dan ahli bahasa. Hal ini sesuai dengan Sugiarti, dkk (2017) yang menyatakan bahwa penilaian dari hasil validasi dari para validator menentukan kelayakan model yang dikembangkan. Dari hasil penilaian dari validator inilah peneliti akan memperoleh masukan dan kemudian melakukan revisi untuk kelayakan hasil penelitiannya. Sejalan dengan Dewy, dkk (2016) yang menjelaskan kegiatan validasi bertujuan untuk memberikan penilaian kevalidan atau kelayakan suatu model pembelajaran untuk digunakan. Lebih lanjut lagi Murtono (tanpa tahun) menjelaskan bahwa penilaian oleh validator sangat penting terhadap suatu instrumen agar instrumen tersebut dapat dipertanggungjawabkan sebelum diujicobakan di lapangan.

Selain melalui proses validasi, penentuan kelayakan model ini juga melalui proses uji keterbacaan oleh mahasiswa. Hal ini dilakukan untuk mengetahui sejauh mana model yang telah dikembangkan dapat digunakan dengan mudah, terutama dalam penyajian bahasa yang jelas dan mudah dipahami oleh mahasiswa. Hasil ini sesuai dengan Dewy, dkk (2016) yang menjelaskan bahwa pengembangan model pembelajaran haruslah menyajikan bahasa dan kalimat yang jelas, komunikatif serta mudah dipahami. Selain itu, kelayakan model JINEMAM untuk digunakan dalam proses pembelajaran dikarenakan model ini dalam pelaksanaannya terkandung unsur penyajian gambar, diskusi, presentasi dan game. Keempat unsur tersebut dalam langkah model yang dikembangkan diyakini akan mampu menarik minat dan motivasi peserta didik dalam mengikuti proses pembelajaran.

Kelayakan model JINEMAM juga diperoleh dari poin yang tertera dalam lembar validasi yang menyatakan bahwa salah satu kelebihan model JINEMAM memotivasi dan menimbulkan ketertarikan mahasiswa dalam proses pembelajaran. Hal ini dikarenakan dalam aplikasi JINEMAM menggunakan gambar-gambar. Penyajian gambar dalam langkah awal JINEMAM secara tidak langsung akan menarik perhatian peserta didik untuk fokus kepada proses pembelajaran. Hal ini sesuai dengan Irfan (2017) yang menyatakan bahwa manfaat media gambar salah satunya adalah menumbuhkan daya tarik peserta didik terhadap proses pembelajaran. Lebih jelas lagi Parmin (2009) menyatakan gambar dapat pula memotivasi peserta didik dengan menarik perhatian mereka, menyita perhatiannya serta menggerakkan respons emosionalnya. Nurjannah (2018) juga menjelaskan bahwa adanya media gambar akan lebih menarik perhatian peserta didik karena peserta didik lebih menyukai gambar-gambar daripada sekedar bacaan tulisan saja. Selain itu media gambar juga membuat proses pembelajaran lebih efektif dan terperinci (Parmin, 2009).

Selanjutnya model JINEMAM layak digunakan karena dalam poin validasi juga terdapat kelebihan JINEMAM yang melatih mahasiswa untuk berkomunikasi. 
Formatif: Jurnal Ilmiah Pendidikan MIPA

Vol. 9, No. 4, December 2019, pp. 281-290

p-ISSN: 2088-351X

e-ISSN: 2502-5457

DOI: http://dx.doi.org/10.30998/formatif.v9i4.3489

Kemampuan komunikasi peserta didik dalam hal ini dilatih dalam proses diskusi dan presentasi. Dalam proses diskusi ini terdapat proses tanya jawab, di mana terdapat unsur pertanyaan yang akan membuat siswa dilatih kemampuannya untuk menjawab sehingga peserta didik akan terlibat langsung dalam proses pembelajarannya. Pendapat ini sejalan dengan Laksono dan Yuniarti (2019) yang menyatakan bahwa penggunaan pertanyaan dapat melibatkan peserta didik dalam proses belajar serta menjadikan mereka lebih tertantang untuk mempersiapkan jawabannya. Adanya proses diskusi serta presentasi juga membuat proses pembelajaran tidak membosankan, karena tidak didominasi oleh pendidik saja. Hal ini sesuai dengan Sunistini Luh, Arini, \& Margunayasa (2013) yang menjelaskan bahwa diskusi mengakibatkan proses belajar yang berlangsung akan lebih berpusat kepada peserta didik. Selain itu kegiatan diskusi dan presentasi akan melatih peserta didik untuk berinteraksi dengan temannya, sehingga tercipta suasana pembelajaran yang interaktif dan menarik. Hal tersebut menunjukkan bahwa model JINEMAM merupakan salah satu model pembelajaran kooperatif, pelaksanaannya terdapat proses kerja sama dan interaksi antar peserta didik.

\section{PENUTUP}

Berdasarkan hasil analisis data dari setiap tahapan define, design dan develop dalam pengembangan model pembelajaran terutama melalui proses validasi baik dari ahli model pembelajaran dan ahli bahasa serta uji keterbacaan, ditemukan sebelas langkah pembelajaran model pembelajaran JINEMAM yang layak untuk digunakan dalam proses pembelajaran.

\section{DAFTAR PUSTAKA}

Arikunto, S. 1993. Prosedur Penelitian Suatu Pendekatan Praktik (Edisi Revisi). Jakarta:Rineka Cipta

Arikunto, S. 2008. Dasar-Dasar Evaluasi Pendidikan. Jakarta : Bumi Aksara

Dewi, N. P., Negara, I. A. O \& Suadnyana, I. N. (2014). Pengaruh penerapan model pembelajaran kooperatif tipe examples non-examples berbasis lingkungan terhadap hasil belajar IPA siswa kelas V SD Negeri Gugus Kapten Japa Denpasar Utara tahun ajaran 2013/2014. Jurnal Mimbar, 2 (1). https://www.ejurnal.com/2015/06/model-pembelajaran-examples-non.html

Dewy, M.S, Ganefri, Kusumaningrum. (2016). Pengembangan model pembelajaran berbasis produk pada mata kuliah praktik elektronika daya. Jurnal Ilmiah Pendidikan Teknik Elektro (VOLT). 1(1), 15-28

Eka, A., Ramli, M., \& Suciati. (2017). Uji kelayakan modul animalia kontekstual berbasis level of inquiry untuk siswa SMA di wilayah pesisir. Jurnal Bioedukatika, 5(2), 39-45. https://doi.org/10.26555/bioedukatika.v5i2.6482

Irfan. (2017). Pengaruh Penggunaan Media Gambar Terhadap Kemampuan Bercerita Dalam Bahasa Bugis Siswa Kelas VIII SMP Negeri 4 Sinjai Timur. Universitas Negeri Makasar. http://jurnal.untirta.ac.id/index.php/VOLT/article/view/806

Laksono, R.D. \& Yuniari, A.P. (2019). Mathematics learning achievement with snowball throwing for kinestetic learning style students. Formatif: Jurnal Ilmiah Pendidikan MIPA, 9 (1), 23-32. http://dx.doi.org/10.30998/formatif.v9i1.2849

Maulidiyah. (2014). Pengaruh Model Pembelajaran Kooperatif Tipe Make a Match Terhadap Hasil Belajar Siswa. Universitas Islam Negeri Syarif Hidayatullah. 
Formatif: Jurnal Ilmiah Pendidikan MIPA

Vol. 9, No. 4, December 2019, pp. 281-290

p-ISSN: 2088-351X

e-ISSN: 2502-5457

DOI: http://dx.doi.org/10.30998/formatif.v9i4.3489

http://repository.uinjkt.ac.id/dspace/bitstream/123456789/25408/1/MAULIDIYA H-FITK.pdf

Murtono. Tanpa tahun. Langkah-langkah Pengembangan Instrumen Yang Akuntabel, Logis, Dan Sistematis Untuk Peningkatan Kualitas Hasil Penelitian. http://eprints.umk.ac.id/213/1/SOSIAL_BUDAYA_JUNI_2010.pdf

Musyahidin, A. Shofi. (2015). Pengaruh perpaduan model pembelajaran kooperatif tipe think pair share dengan metode guided note taking terhadap hasil belajar siswa pada standar kompetensi memperbaiki cd player kelas XI Tav di SMK Negeri 2 Surabaya. Jurnal Pendidikan Teknik Elektro, 04(02), 551-556. https://jurnalmahasiswa.unesa.ac.id/index.php/jurnal-pendidikan-teknikelektro/article/view/11759

Nurjannah. (2018). Pengaruh media gambar terhadap motivasi belajar pelajaran bahasa Indonesia kelas III SDN Pasi Pinang. Bina Gogik, 5(1), 71-78. http://ejournal.stkipbbm.ac.id/index.php/pgsd/article/view/17

Parmin. (2009). Pengaruh Penggunaan Media Model Dan Gambar Terhadap Prestasi Belajar Ilmu Pengetahuan Alam Ditinjau Dari Motivasi Belajar Siswa. Published Tesis. Universitas Sebelas Maret. https://eprints.uns.ac.id/4554/1/167140309201011051.pdf

Pratiwi, D. H. (2009). Terhadap Prestasi Belajar Siswa Kelas VII Di SMP NEGERI I Batang Tahun Ajaran 2008 / 2009 ( Studi Pada Mata Pelajaran Geografi Materi Pokok Bentuk - Bentuk Muka Bumi) Published Skripsi. Universitas Negeri Semarang. lib.unnes.ac.id/970/1/2485.pdf

Suciati, Rien. (2013) Model Pembelajaran Example Non Example [online]. Tersedia di : http://riensuciati99.blogspot.com/2013/04/model-pembelajaran-examples-nonexamples.html. [Diakses 28 Juli 2019].

Sudjana, N. 2005. Penilaian Hasil Proses Belajar Mengajar. Bandung: PT. Remaja Rosdakarya.

Sugiarti, Sri, dkk. (2017). Validitas model pembelajaran batu obsidianko (baca, tulis, observasi, diskusi, analisis, komunikasi) untuk pembelajaran IPA SMP. Jurnal Pembelajaran dan Pendidikan Sains, 2(1), 16-24.

Sunistini Luh, Arini, N. W., \& Margunayasa, I. G. (2013). Penerapan model snowball throwing berbantuan media sederhana untuk meningkatkan hasil belajar matematika siswa di SD No 1 Petandakan. Jurnal Mimbar, 1(1).

Trisianawati, E., Djudin, T., \& Setiawan, R. (2016). Pengaruh model pembelajaran kooperatif tipe jigsaw terhadap hasil belajar siswa pada materi vektor di kelas $\mathrm{X}$ SMA Negeri 1 Sanggau Ledo. Jurnal Penelitian Fisika Dan Aplikasinya (JPFA), 6(2), 51-60. DOI: 10.26740/jpfa.v6n2.p51-60

Thiagarajan, S., et al. 1974. Instructional Development for training teacherof expectional Children. Minneapolis. Minnesota. Leadership Training Institute.

Zahroul, C., \& Windy, F. (2014). Model pembelajaran kooperatif teknik make a match sebagai upaya peningkatan aktivitas dan hasil belajar siswa kelas IV SD dalam pembelajaran IPS pokok bahasan perkembangan teknologi produksi, komunikasi dan transportasi. Jurnal Pedagogi, 1(1), 39-46.

Zubaidah, Siti. 2016. Keterampilan Abad ke-21: Keterampilan Yang Diajarkan Melalui Pembelajaran. Disampaikan pada Seminar Nasional Pendidikan dengan tema "Isu-isu Strategis Pembelajaran MIPA Abad 21, tanggal 10 Desember 2016 di Program Studi Pendidikan Biologi STKIP Persada Khatulistiwa Sintang Kalimantan Barat https://www.researchgate.net/publication/318013627 KETERAMPILAN ABAD KE-21 KETERAMPILAN YANG DIAJARKAN MELALUI PEMBELAJARAN 